\title{
Analisis Kandungan Mineral Logam Besi (Fe) Batuan Dikawasan Pertambangan Emas Desa Sekotong dengan Menggunakan Metode AAS
}

\author{
Baiq rina amalia safitri, \\ Program studi pendidikan teknologi informasi FSTT UNDIKMA \\ Email : laluimam44@gmail.com
}

\begin{abstract}
ABSTRAK : Telah dilakukan penelitian dengan judul: "analisis kandungan mineral logam besi (Fe) batuan dikawasan pertambangan emas desa sekotong lombok barat dengan menggunakan metode AAS". Yang bertujuan untuk menentukan konsentrasi unsur logam besi (Fe) pada sampel batuan yang berada dikawasan pertambangan emas Desa sekotong Lombok barat. Metode yang digunakan dalam penelitian ini yaitu dengan metode Atomic Absorption Spectroskopi (AAS). Hasil penelitian menunjukkan bahwa sampel batuan memiliki konsentrasi unsur logam besi $(\mathrm{Fe})$ sebesar 1,39 \% dari 0,5 gram sampel batuan.
\end{abstract}

Kata kunci: batuan tambang, mineral logam besi, AAS.

\section{PENDAHULUAN DAN KAJIAN LITERATUR}

Menurut (Peraturan Gubernur Nusa Tenggara Barat Nomor 24 tahun 2015), tentang pelaksanaan kegiatan usaha pertambangan mineral dan batubara, menimbang: bahwa untuk melaksanakan ketentuan Pasal 14 ayat (1) Undang Undang Nomor 23 Tahun 2014 tentang Pemerintahan Daerah, serta Pasal 9 ayat (3), Pasal 11, Pasal 13 ayat (2), Pasal 14 ayat (3), Pasal 15 ayat (3), Pasal 19, Pasal 25 ayat (5), Pasal 27, Pasal 29 ayat (4), Pasal 30 ayat (4), Pasal 57 ayat (3), dan Pasal 60 ayat (3), tentang Peraturan Daerah Nomor 4 Tahun 2012 tentang Pengelolaan Pertambangan Mineral dan Batubara yang baik dan benar. Perlu melaksanakan Peraturan Gubernur tentang Pelaksanaan Kegiatan Usaha Pertambangan Mineral dan Batubara, supaya terhindar dari dampak negatif pertambangan [1].

Namun, pertambangan yang ada di kecamatan sekotong Lombok Barat ini didominasi oleh pertambangan yang tidak dinaungi oleh perusahaan besar dan izin dari pemerintah setempat atau penambangan yang masih dilakukan secara tradisional sehingga kandungan mineral yang diambil dalam batuan hanya emas tanpa memperhatikan kandungan mineral lain dan bagi masyarakat sekitar memiliki keterbatasan peralatan pertambangan yang tidak mendukung. Masalah pembuangan limbah yang tidak mengikuti peraturan hampir selalu berdampak negatif bagi lingkungan, baik dari segi estetika kesehatan lingkungan, maupun bahan beracun berbahaya dari pabrik [2]. Secara stratigratif batuan penyusun di wilayah pertambangan kecamatan Sekotong dominannya masih merupakan batuan vulkanik terdiri dari andesit, breksi vulkanik, dan sebagian batuan sedimen (tufa berlapis). Baik diluar maupun di dalam area pengambilan contoh batuan [3].
Salah satu kandungan mineral batuan yang akan diuji pada batuan tersebut adalah mineral logam besi. Besi adalah unsur kimia dengan simbol Fe (dari bahasa Latin: ferum) dan nomor atom 26. Merupakan logam dalam deret transisi pertama. Ini unsur paling umum di bumi berdasarkan massa, membentuk sebagian besar bagian inti luar dan dalam bumi. Besi adalah unsur keempat terbesar pada kerak bumi [4]

Sejauh ini limbah tambang mulai mencemari kawasan di Sekotong, seperti pencemaran di lokasi pembuatan garam rakyat di Cendi Manik dan adanya ternak mati diduga meminum air bekas sisa bahan tambang di daerah Pelangan [5].

Limbah tambang yang dimaksud sisa-sisa dari pengolahan emas yang dilakukan dengan tradisional menggunakan gelondongan. Dimana air sisa pengolahan emas secara tradisional ini akan mengalir ke sungai melewati saluran irigasi yang akan mencemari lingkungan dan air sekitar.

Salah satu limbah tambang berbahaya yakni Besi $(\mathrm{Fe})$, logam berat $\mathrm{Fe}$ merupakan logam berat essensial yang keberadaannya dalam jumlah tertentu sangat dibutuhkan oleh organisme hidup, namun dalam jumlah yang berlebih dapat menimbulkan efek racun (Supriyantini \& Endrawati, Kandungan Logam Berat Besi (Fe) Pada Air, Sedimen, dan Kerang Hijau (Perna Viridis) di Perairan Tanjung Emas Semarang, Juni 2015)

Oleh karena itu, untuk mengurangi dampak negatif dari pertambangan, peneliti mengambil sampel batuan pertambangan di desa Sekotong tengah. Kemudian batuan tersebut diuji menggunakan metode Atomic Absobtion Spectrofotometer (AAS) supaya mendapatkan hasil yang maksimal 


\section{METODE PENELITIAN}

Spektrometri Serapan Atom (SSA) adalah suatu alat yang digunakan pada metode analisis untuk penentuan unsurunsur logam dan metalloid yang pengukurannya berdasarkan penyerapan cahaya dengan panjang gelombang tertentu oleh atom logam dalam keadaan bebas (Skoog et al., 2000). Langkah-langkah dari penelitian yang dilakukan yaitu persiapan ampel batuan tambang, analisa unsur menggunakan metode AAS dan terakhir analisis potensi unsur penyusun batuan tambang.

a) Waktu dan Tempat Penelitian

Penelitian ini dilaksanakan pada tanggal 6 April 2019 sampai 10 Juli 2019. Sampel dalam penelitian ini diambil dari kawasan pertambangan emas di Desa Sekotong Tengah, Kecamatan Sekotong, Kabupaten Lombok Barat, Provinsi Nusa Tenggara Barat. Sampel yang diambil dalam bentuk bongkahan yang dinamakan Hand-Sample. Hand Sample tersebut akan di preparasi dan dianalis kandungan mineral sampel yang dilakukan di Laboratorium Balai Pengkajian Teknologi Pertanian (BPTP) NTB. Adapun tahap preparasi sampel dilakukan adalah penggerusan sampel kemudian pengayakan sampel.

b) Jenis Penelitian

Jenis penelitian ini adalah penelitian yang bersifat deskriptif. Pada penelitian ini menggunakan pemeriksaan laboratorium secara kualitatif dengan metode Atomic Absobtion Spectrofotometer (AAS). Penelitian kualitatif dilakukan bertujuan untuk mengetahui ada tidaknya kandungan fosfor yang terdapat di batuan tambang Sekotong.

c) Alat dan Bahan:

1. Neraca analitik tiga desimal

2. Tabung digestion \& blok digestion

3. Pengocok tabung

4. Dispenser

5. Tabung reaksi

6. Spektrophotometer UV-VIS

7. Spektrofotometer serapan atom (SSA)

\section{Pereaksi:}

- $\mathrm{HNO}_{3}$ pekat $(65 \%)$ p.a.

- $\mathrm{HClO}_{4}$ pekat $(60 \%)$ p.a.

- Standar 0 (larutan $\mathrm{HClO}_{4}$ 0,6\%) Dipipet $1 \mathrm{ml}$ $\mathrm{HClO}_{4}$ pekat $(60 \%)$ ke dalam labu ukur $100 \mathrm{ml}$ yang telah berisi air bebas ion kira-kira setengahnya,goyangkan dan tambahkan lagi air bebas ion hingga tepat $100 \mathrm{ml}$ (pengenceran 100 $\mathrm{x})$.
- Larutan La 2,5\%

Ditimbang 44,14 $\mathrm{g} \mathrm{LaCl}_{3}$, dilarutkan dengan air bebas ion, kemudian diimpitkan tepat 11 .

- Larutan La 0,25\%

Larutan La 2,5\% diencerkan $10 \mathrm{x}$ dengan air bebas ion.

- Standar pokok Fe 1.000 ppm.

- Standar campur Fe 100 ppm. 10,0 ml standar pokok 1.000 ppm Fe dicampurkan dalam labu ukur $100 \mathrm{ml}$. Tambahkan air bebas ion hingga tepat $100 \mathrm{ml}$.

- Standar campur Fe 10 ppm.

Dipipet $10 \mathrm{ml}$ standar campur Fe (100 ppm), Mn (100 ppm), $\mathrm{Cu}$ (50 ppm) dan Zn (25 ppm) ke dalam labu ukur $100 \mathrm{ml}$. Tambahkan perlahan $1 \mathrm{ml} \mathrm{HClO}_{4}$ pekat dan impitkan dengan air bebas ion hingga tepat 100 $\mathrm{ml}$.

- Deret standar campur Fe 0-10 ppm. Dipipet standar campur sebanyak $0 ; 1 ; 2 ; 4 ; 6 ; 8$ dan $10 \mathrm{ml}$ dan masing-masing dimasukkan ke dalam tabung reaksi. Tambahkan larutan standar 0 hingga volume setiap tabung menjadi $10 \mathrm{ml}$, kocok.

d) Prosedur Penelitian

Ditimbang $0,5 \mathrm{~g}$ contoh tanah halus $<0,5 \mathrm{~mm} \mathrm{ke}$ dalam tabung digest, ditambahkan $5 \mathrm{ml}$ asam nitrat p.a dan $0,5 \mathrm{ml}$ asam perklorat p.a, didiamkan satu malam. Esoknya dipanaskan pada suhu $100{ }^{\circ} \mathrm{C}$ selama 1 jam 30 menit, kemudian suhu ditingkatkan menjadi $130{ }^{\circ} \mathrm{C}$ selama $1 \mathrm{jam}$, suhu ditingkatkan lagi menjadi $150{ }^{\circ} \mathrm{C}$ selama 2 jam 30 menit (sampai uap kuning habis, bila masih ada uap kuning waktu pemanasan ditambah lagi), setelah uap kuning habis suhu ditingkatkan menjadi $170 \quad{ }^{\circ} \mathrm{C}$ selama 1 jam, kemudian suhu ditingkatkan menjadi $200{ }^{\circ} \mathrm{C}$ selama 1 jam (hingga terbentuk uap putih). Destruksi selesai dengan terbentuknya endapan putih atau sisa larutan jernih sekitar 0,5 ml. Ekstrak didinginkan kemudian diencerkan dengan air bebas ion menjadi $25 \mathrm{ml}$, lalu dikocok hingga homogen, biarkan semalam.Fe diukur.

Kadar Fe $(\mathrm{ppm})=$ ppm kurva $\mathrm{x} \mathrm{ml} \mathrm{ekstrak/1.000} \mathrm{ml} \mathrm{x}$ $1.000 \mathrm{~g}$ (g contoh $)^{-1} \mathrm{x} \mathrm{fk}$

$=$ ppm kurva $\times 50 / 1.000 \times 1.000 / 0,5 \times \mathrm{fk}$ $=\mathrm{ppm}$ kurva $\mathrm{x} 100 \mathrm{x} \mathrm{fk}$

Keterangan:

Ppm kurva $=$ kadar contoh yang didapat dari kurva hubungan antara kadar deret standar dengan pembacaannya setelah dikoreksi blanko. 


$\begin{aligned} 100 & =\text { konversi ke \% (pada satuan \%) } \\ \mathrm{Fk} & \text { faktor koreksi kadar air=100/(100-\%kadar } \\ & \text { air) } \\ \mathrm{Fp} & \text { faktor pengenceran }\end{aligned}$

\section{HASIL DAN PEMBAHASAN}

Berdasarkan hasil analisis data pengujian dapat ditarik kesimpulan bahwa: (1) pengujian kandungan mineral logam besi pada batuan tambang dapat dilakukan dengan metode AAS (2) terdapat 1,39\% kandungan mineral logam besi pada batuan tambang di Desa sekotong Lombok barat. Salah satu limbah tambang berbahaya yakni Besi (Fe), logam berat $\mathrm{Fe}$ merupakan logam berat essensial yang keberadaannya dalam jumlah tertentu sangat dibutuhkan oleh organisme hidup, namun dalam jumlah yang berlebih dapat menimbulkan efek racun.

(Moshood Onifade, 2019) Mining engineering practice involves the extraction of minerals from the earth with significant effect to the environment. Though this operation is important to living better lives but causes more damage to the landscape than ever before. The results for heavy metals concentration obtained from the soil samples are 0.30, 0.90, 0.09, 0.995 and $39.40 \mathrm{mg} / \mathrm{kg}$ for lead $(\mathrm{Pb})$, copper $(\mathrm{Cu})$, cadmium $(\mathrm{Cd})$, zinc $(\mathrm{Zn})$ and iron $(\mathrm{Fe})$ respectively.

(Fathurrahmi, 2012) $\mathrm{Ca}, \mathrm{Fe}, \mathrm{Mg}$ and $\mathrm{Na}$ are contents in samples of bentonite Clay being determined by using Atom Absorption Spectrophotometer (AAS). Each part of the substance from yellow bentonite clays and white bentonite clays were measured and analysed its content with three times repetition. Natural-bentonite clays of Pacitan from East Java contained the minerals $\mathrm{Ca}, \mathrm{Mg}, \mathrm{Fe}$ and $\mathrm{Na}$ with mean values of the gratuity $\mathrm{Ca} 0.0127 \% \mathrm{Mg}$ $0.24655 \%, \mathrm{Fe} 0.56178 \%$, and $\mathrm{Na} 0.14122 \%$ for yellow bentonite clays (A). White bentonite clays (B) consisted of minerals $\mathrm{Fe}, \mathrm{Mg}, \mathrm{Na}$, and $\mathrm{Ca}$ with mean values of gratuity $\mathrm{Ca} 0.01856 \%, \mathrm{Mg} 0.30067 \%, \mathrm{Fe} 0.61235 \%$, and $\mathrm{Na}$ $0.1608 \%$, respectively.

Logam berat Fe dalam sampel air, sedimen dan kerang hijau dianalisis di Laboratorium Balai Besar Teknologi Pencegahan Pencemaran Industri (BTPPI) Semarang dengan menggunakan metode AAS (Atomic Absorption Spectrophotometry). Hasil penelitian menunjukkan bahwa perairan Tanjung Emas masih dalam taraf terkontaminasi logam Fe. Hasil yang bervariasi yakni antara 0,031-0,371 $\mathrm{mg} / \mathrm{L}$ (November) dan 0,105-0,234 mg/L (Desember). (Supriyantini \& Endrawati, Juni 2015).

(Sari, Juli 2016 ) AAS method shows the mineral elements / compounds contained in the rock are $1.77 \% \mathrm{Fe}, 1.16 \%$ $\mathrm{Cu}, 90.43 \% \mathrm{SiO} 2 \%$ and 2:05.\% $\mathrm{Al} 2 \mathrm{O} 3$. The results of three methods identify that rock mining in Bukit 12 contain dominant minerals namely silicon oxide ( $\mathrm{SiO} 2), \mathrm{Cu}, \mathrm{Fe}$ and $\mathrm{Al}$ (Al2O3).Bagian ini menyajikan hasil penelitian. Hasil penelitian dapat dilengkapi dengan tabel, grafik (gambar), dan/atau bagan. Bagian pembahasan memaparka hasil pengolahan data, menginterpretasikan

\section{KESIMPULAN}

Hasil pengujian pada batuan tambang sudah mencerminkan dampak negatif yang dapat dirasakan masyarakat, untuk itu perlu sekiranya penambangan dilakukan dengan baik dan benar (good mining practice).

\section{DAFTAR PUSTAKA}

[1] Peraturan Gubernur Nusa Tenggara Barat Nomor 24 tahun 2015.

[2] Reginawanti, d. (2011 ). Pemanfaatan Limbah Tahu dalam Pengomposan Sampah Rumah Tangga untuk Meningkatkan Kualitas Mikrobiologi Kompos. Bandung: Universitas Padjadjaran.

[3] Putra, B. N. (2015). Prospeksi mineral logam di kecamatan sekotong, kabuaten lombok barat, provinsi nusa tenggara barat tahuun 2015 . kelompok penyelidikan mineral, pusat sumber daya geologi, 21.

[4] Wikipedia. (2019, Agustus 31). Besi. Retrieved Januari 28, 2020, from Wikipedia Ensiklopedia Bebas: https://id.wikipedia.org/wiki/Besi

[5] PT. SUARA NTB PERS: https://www.suarantb.com/gaya.hidup/lingkung an/2016/10/10419/persoalan.limbah.mulai.resa hkan.masyarakat.sekotong/ 